\title{
Mythicomyces corneipes, a rare agaric, in Fennoscandia
}

\author{
SEPPO HUHTINEN and JUKKA VAURAS
}

\begin{abstract}
HUHTINEN, S. \& VAURAS, J. 1992: Mythicomyces corneipes, a rare agaric, in Fennoscandia. - Karstenia 32:7-12.

The taxonomy, distribution and ecology of the rarely collected agaric Mythicomyces corneipes (Fr.) Redhead \& Smith are treated. The species has been collected from six sites in Fennoscandia. These collections also represent the known European distribution. A colour photograph, the morphology and a detailed account of the ecology are presented. Features not reported earlier are the amyloid reaction in the cystidial walls, the dextrinoid reaction of the spores and their small plage.
\end{abstract}

Key words: Agaricales, Basidiomycetes, Mythicomyces corneipes, NW Europe, taxonomy Seppo Huhtinen, Department of Biology, University of Turku, SF-20500 Turku, Finland Jukka Vauras, Herbarium of Abo Akademi University, Department of Biology, SF-20500 Turku, Finland

In 1989 a study was conducted to map the mycoflora of some interesting sites in the commune of Kaarina, in SW Finland. One of the sites to be mapped was a small brook ravine surrounded by a narrow strip of fairly rich spruce forest (Fig. 1). Along the brook, close to running water, a dark-spored Hypholoma- or Phaeocollybia-like basidiomycete was frequently observed. This fungus was very difficult to place in any of the well-known genera. It had minutely roughened, brown spores and metuloid cystidia. Curiously, the apices of the cystidia were amyloid.

In 1990 the fungus was recollected, photographed and finally identified. On the basis of a study by Redhead and Smith (1986), we could determine our collections as Mythicomyces corneipes (Fr.) Redhead \& Smith, a species formerly placed in Psilocybe (Fr.) Quélet. Information from our colleagues and a search of herbaria for other Fennoscandian collections revealed that the species had already been noted and collected more than 10 years earlier in Norway by Dr. Sivertsen (S. Sivertsen, in litt.). Contacting Swedish herbaria clarified the identity of two recent collections (Stridvall \& Stridvall 1991, Stålberg 1991). Mythicomyces corneipes is very rare in Europe and, to our knowledge, is known from only a few localities in Fennoscandia.

As Redhead and Smith (1986) gave a thorough description of the species, it will be only briefly described here. The information on the macroscopic features is based on Fennoscandian material. The measurements of the microscopical features were made on geographically widely separated collections from two continents. The measurements and drawings were made from dried material mounted in $10 \%$ $\mathrm{NH}_{4} \mathrm{OH}$, unless otherwise indicated, using $\times 1500$ magnification. The colours are given according to the codes of Cailleux (1981) and Küppers (1978).

\section{Mythicomyces corneipes}

Agaricus corneipes Fr., Monogr. Hymenomyc. Suec. 2:304. 1863. - Psilocybe corneipes (Fr.) P. Karsten, Bidr. Känned. Finl. Nat. Folk 32:504. 1879. - Mythicomyces corneipes (Fr.) Redhead \& Smith, Canadian J. Bot. 64:643. 1986. - Neotype: U.S.A., Idaho, Valley Co., Payette Lakes, in boggy area, X.1943 W.B. Gruber $P-88$, det. S.A. Redhead ( $\mathrm{MICH}$, examined).

Pileus $0.8-2.6 \mathrm{~cm}$ in diam, $0.4-1.0 \mathrm{~cm}$ high, conical when young, later convex, consistently with a broad umbo, up to $4 / 5$-striate, clearly hygrophanous, with a greasy shine, smooth. Colour in centre reddish brown (Cailleux P45, P60, R47; Küppers $\mathrm{Y}_{99} \mathrm{M}_{50} \mathrm{C}_{50}$ ), at margin yellowish brown (M79, $\mathrm{Y}_{70} \mathrm{M}_{30} \mathrm{C}_{20}$ ) when fresh; in dry condition pilei Buff (N80, $\left.\mathrm{Y}_{50} \mathrm{M}_{30} \mathrm{C}_{10}\right)$. Lamellae adnate to narrowly adnate, in fresh condition colour first Straw (K79), later more greyish brown; in dry condition Hazel (P65) to Cinnamon (N69). Lamellulae present. Stipe $3.5-7.5 \mathrm{~cm}$ long, 1-2 mm thick, of even thickness, slightly flexuous, 


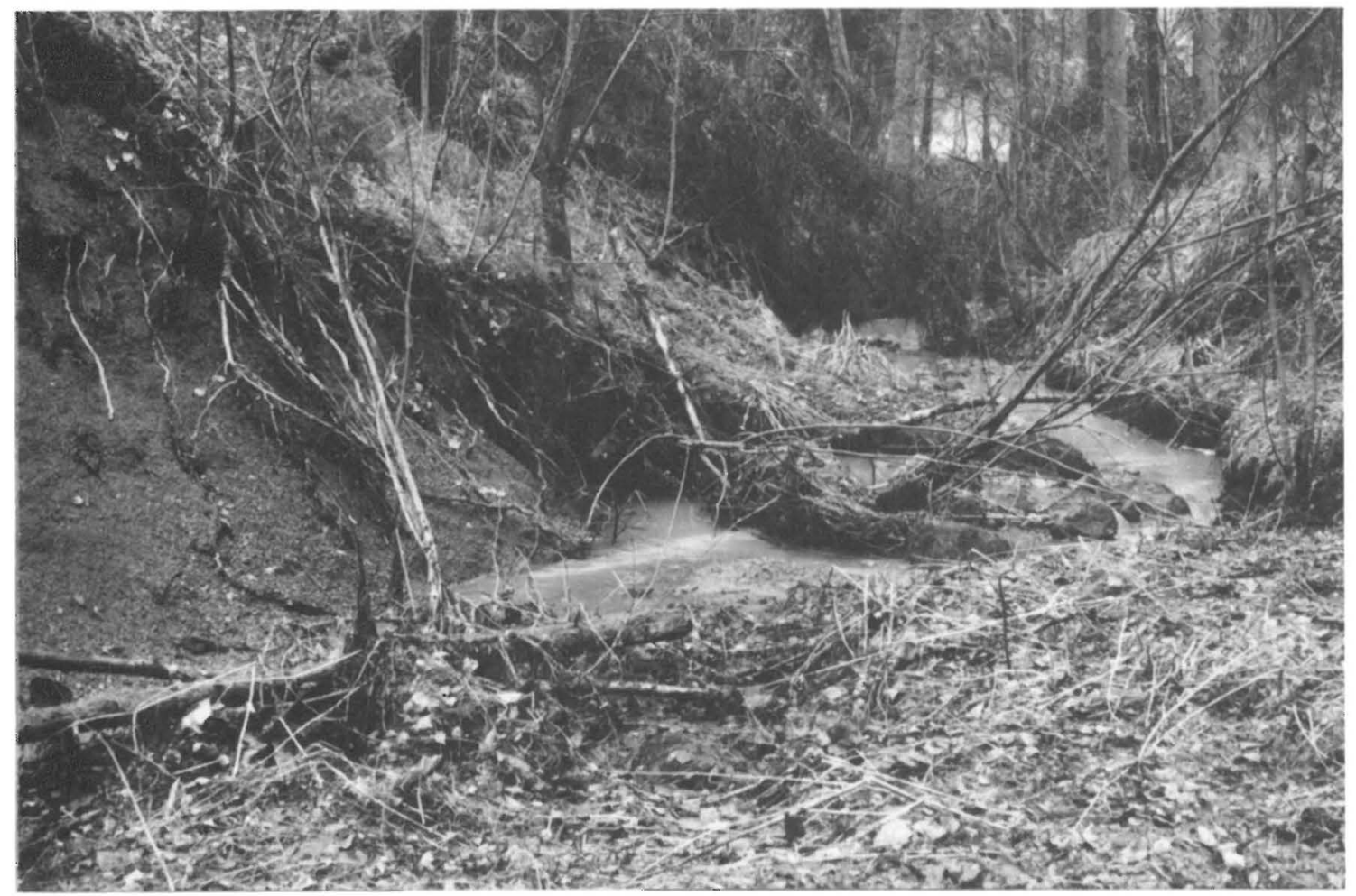

Fig. 1. The ravine Juopinkrotti in Kaarina, SW Finland, photographed in May 1991. — Photo Jukka Vauras.

glossy and smooth except for $2-3 \mathrm{~mm}$ at the apex, where slightly pruinose, base not rooting; in fresh condition colour at apex reddish brown $\left(\mathrm{Y}_{70} \mathrm{M}_{60} \mathrm{C}_{40}\right)$, becoming much darker towards base, where blackish brown $\left(\mathrm{Y}_{90} \mathrm{M}_{99} \mathrm{C}_{80}\right)$. Odour fungous, taste indistinct to slightly bitter.

Spores 7-9(-10) $\times(4-) 4.5-6(-6.5) \mu \mathrm{m}$, total range of mean values $7.5-8.3 \times 4.7-5.6 \mu \mathrm{m}, \overline{\mathrm{x}}=8.0 \times 5.1 \mu \mathrm{m}$ (7 collections, 140 spores), $\mathrm{Q}=1.4-1.8$, the average for 7 collections being 1.57, ovoid to ellipsoid, often somewhat inequilateral, minutely roughened, with plage, lacking germ-pore, some uniguttulate in lactic acid and $\mathrm{NH}_{4} \mathrm{OH}$; spores in mass greyish brown (P69), pale greyish to yellowish brown in $\mathrm{NH}_{4} \mathrm{OH}$ under the microscope, dextrinoid, inamyloid, metachromatic in cresyl blue; guttula blue in cresyl blue. Basidia 24-27 $\times 7-8 \mu \mathrm{m}$, clamped, four-spored. Pleurocystidia $42-71 \times 15-27 \mu \mathrm{m}$, abundant, ventricose, more rarely broadly obclavate, thick-walled, thinwalled at the pedicel, mostly apically smooth, some with prominent, hyaline crystals; walls often irregular in thickness, yellowish in $\mathrm{NH}_{4} \mathrm{OH}$, moderately amy- loid at the apex, not or rarely so in lower parts; contents wine red in cresyl blue. Cheilocystidia similar to more irregular in shape. Caulocystidia $32-55 x$ 9-14 $\mu \mathrm{m}$, cylindrical to clavate, thick-walled, apically rarely amyloid.

\section{Distribution and phenology}

Mythicomyces corneipes is rare to uncommon in North America, where it is widely distributed (Redhead \& Smith 1986). In Europe it is known from six localities in Fennoscandia (Fig. 8), from the Hemiboreal to the Northern Boreal zone. The most recent collection from Sweden (Dalsland, Skållerud, Ryr, 11.IX.1990 A. Stridvall) was not saved, but the material was examined under the microscope and the typical cystidia noted (Stridvall \& Stridvall 1991), so it can be included with confidence. The fruiting period is long, coinciding with the frost-free season; it starts in late July and reaches a peak in mid-September (Fig. 9). In Kaarina, SW Finland, the fruiting 


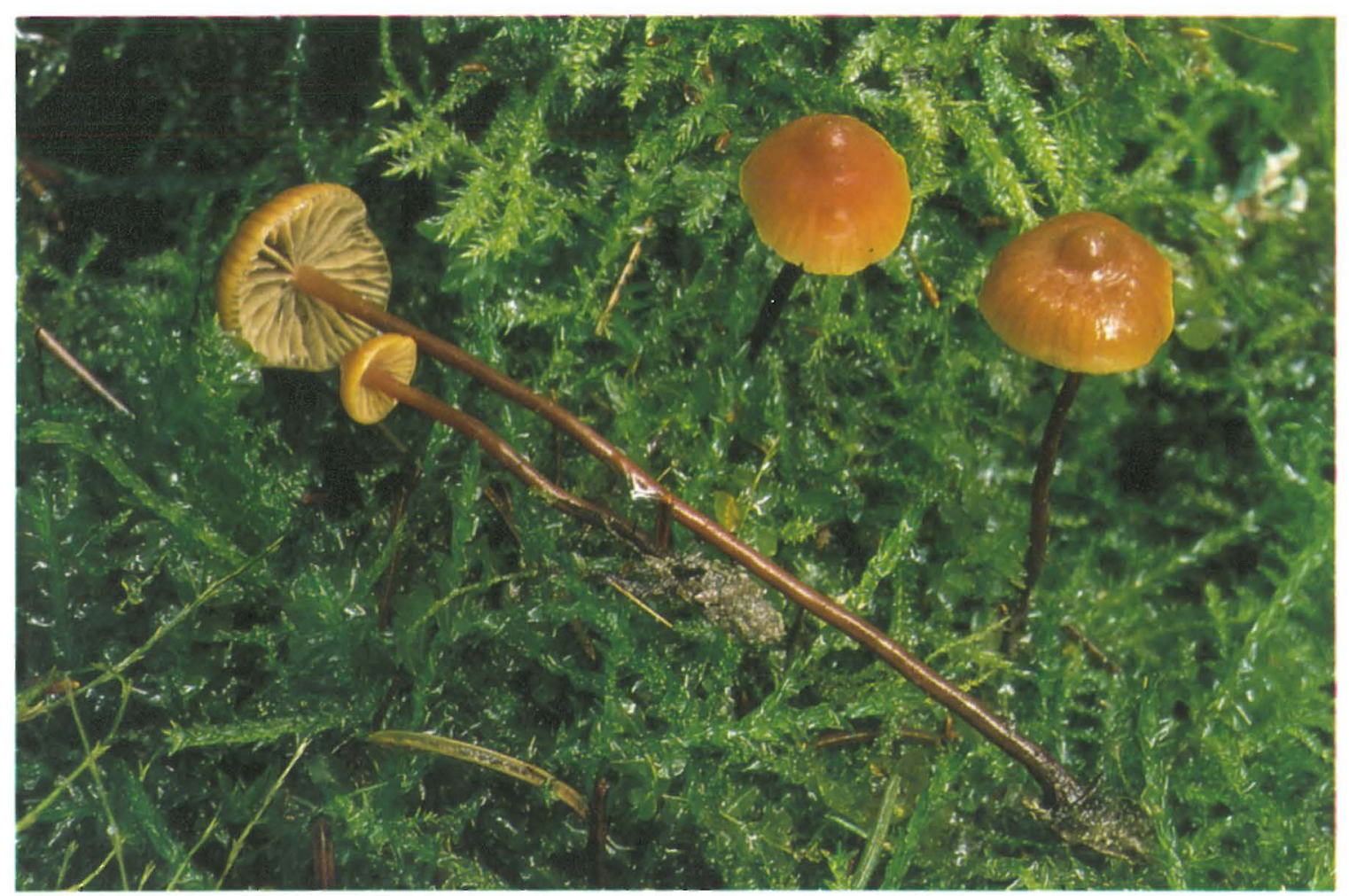

Fig. 2. Fruit bodies of Mythicomyces corneipes, in situ, x 1.5. (Finland, Varsinais-Suomi: Kaarina, Kuusisto, Juopinkrotti, $9 . X .1990$ Huhtinen \& Vauras $5436 \mathrm{~F}$, TURA). — Photo Jukka Vauras.

peaks in late September-early October. At that time several groups of Mythicomyces were found along the brook.

\section{Ecology}

In North America the species is found along the margins of bogs and in sites flooded in the spring. The substrate is plant debris, mainly pieces of wood (Redhead \& Smith 1986). The Norwegian site is a small brook ravine in spruce forest, which is regularly inundated and has relatively open vegetation, without a continuous moss cover. The dominant vascular plants are Stellaria nemorum and Equisetum sylvaticum.

Fig. 3 (Right). Fruit bodies of Mythicomyces corneipes, $\times 1$. (From Huhtinen \& Vauras 5436F, TURA).

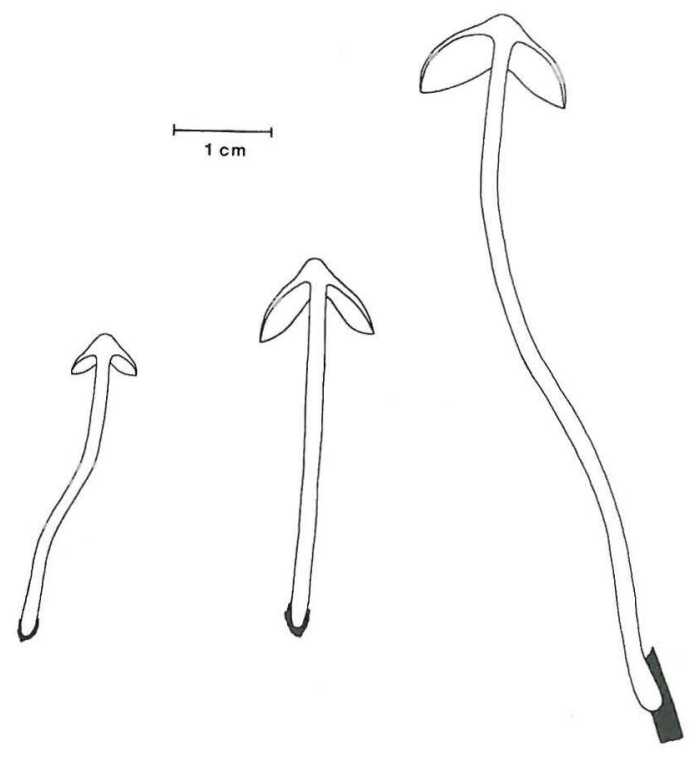



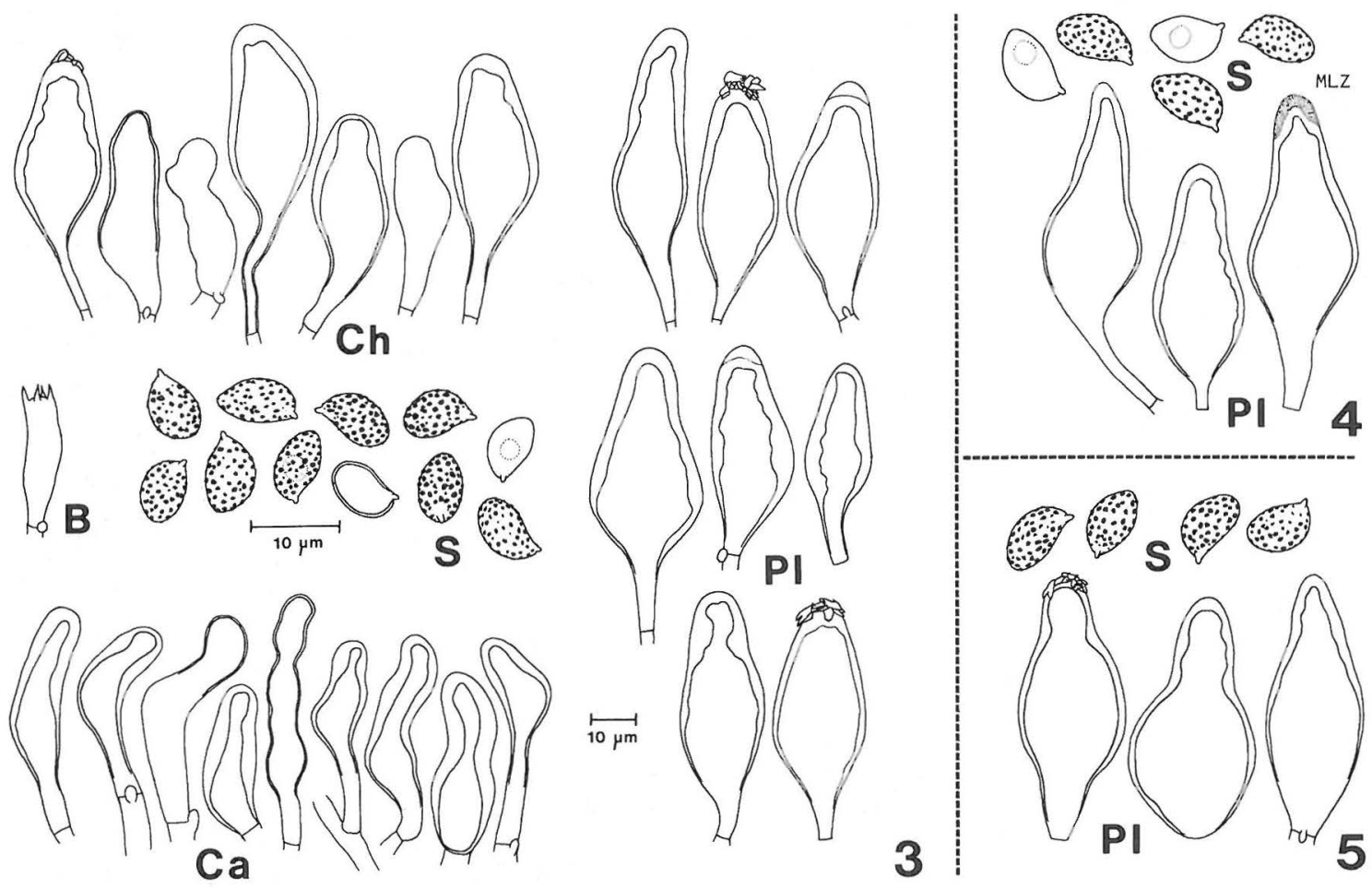

Figs. 4-6. Microscopical details of Mythicomyces corneipes. - 4: Huhtinen \& Vauras 5436F (TURA). - 5: Sivertsen 15. IX.1976 (TRH). - 6: Gruber P-88 (neotype, MICH). Symbols: $\mathrm{Ch}=$ cheilocystidia, B = basidium, $\mathrm{S}=$ spores, $\mathrm{Pl}=$ pleurocystidia, $\mathrm{Ca}=$ caulocystidia at stipe apex. Scales: spores $\times 1000$, others $\times 500$.

Urtica dioica, Rubus idaeus and Alnus incana are also present (S. Silvertsen, in litt.). The recent Swedish collections and the collection from Kuusamo were all

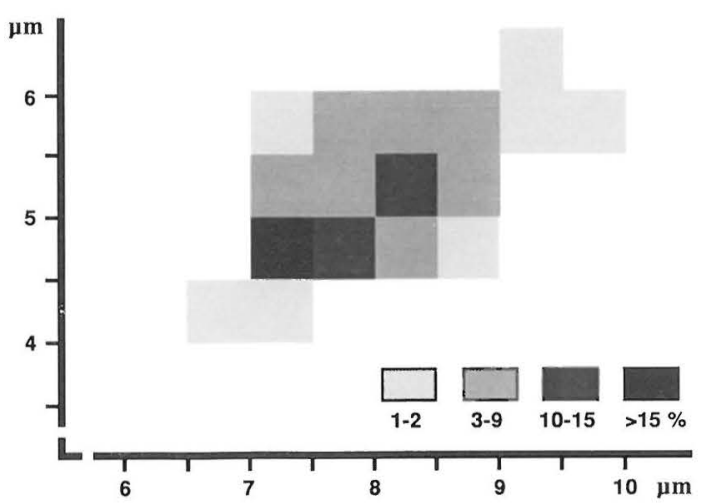

Fig. 7. Percentage sporogram of Mythicomyces corneipes, based on 100 spores (five collections). made from moist, fairy rich forests dominated by Picea abies. In Kuusamo Mythicomyces was found fruiting on a stump.

In Kaarina the inundated brook margins and flats are characterized by Anemone nemorosa, Athyrium filix-femina, Equisetum sylvaticum, Geum rivale, Thelypteris phegopteris, Urtica dioica and Ranunculus repens. Common, but less abundant are Anthriscus sylvestris, Caltha palustris, Cirsium arvense, Hepatica nobilis, Oxalis acetosella, Ribes nigrum, Rubus idaeus, Sambucus racemosa and Sorbus aucuparia. The moss layer is fragmented, mainly consisting of Cirriphyllum piliferum, Hylocomium splendens, Rhytidiadelphus squarrosus, Rhodobryum roseum and Sphagnum squarrosum, and the liverwort Plagiochila asplenioides. In Kaarina Mythicomyces has been found fruiting once on Athyrium rachides, but mostly the fruit bodies occur on mineral soil mixed with litter or on small hardwood and softwood branches partly buried in soil. The $\mathrm{pH}$ reaction of the alluvial soil (both fine sand and clayey soil) along the brook varies between 5.8 and 5.9 . 


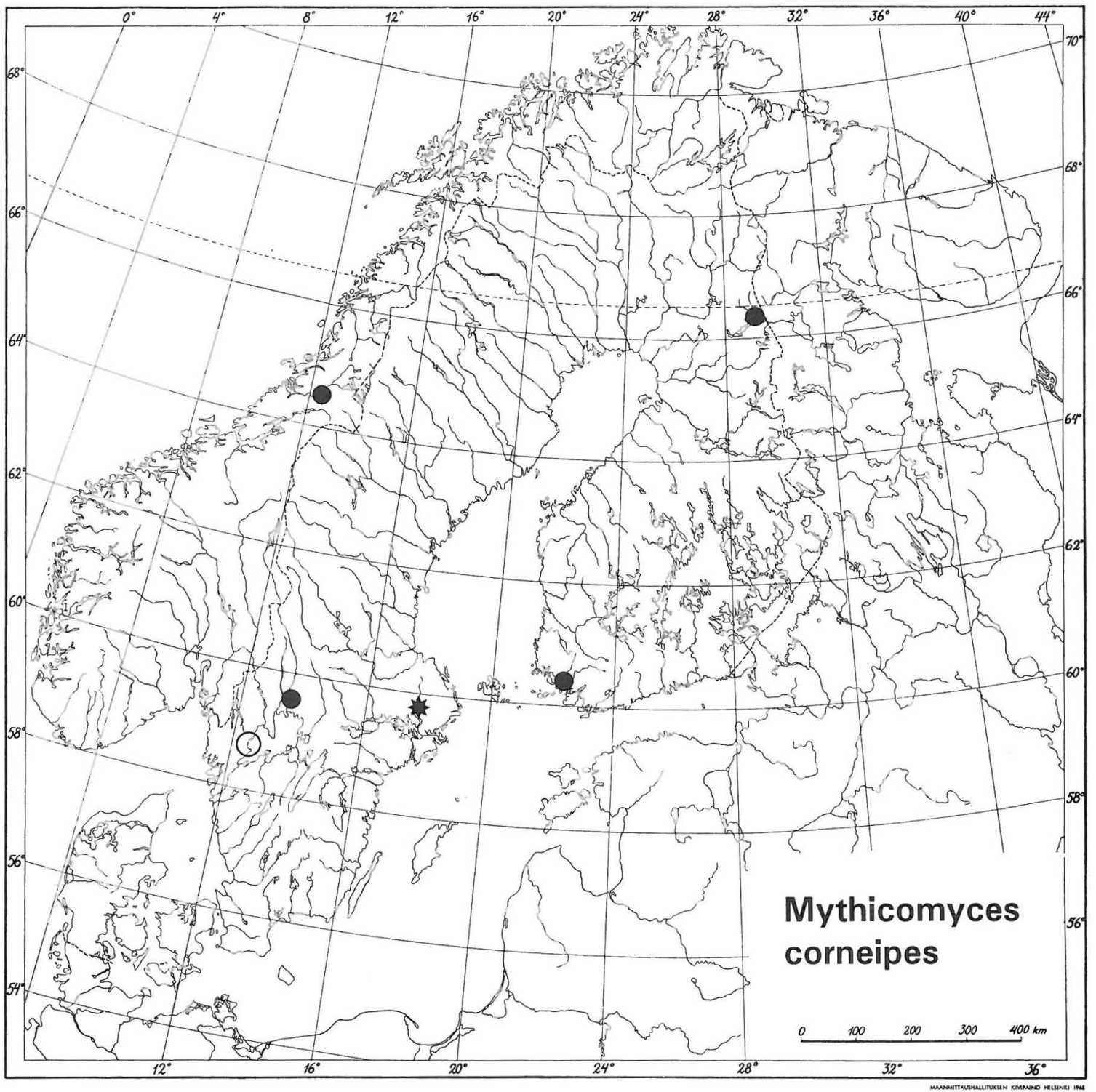

Fig. 8. The distribution of Mythicomyces corneipes in Fennoscandia according to the specimens studied (dots), collection not preserved (open circle) and Fries (1877-1884, star).

\section{Discussion}

The monotypic genus Mythicomyces was established by Redhead and Smith (1986), to accommodate Agaricus corneipes $\mathrm{Fr}$. Due to its rough spores and metuloids, the species could not be left in Psilocybe (Guz-

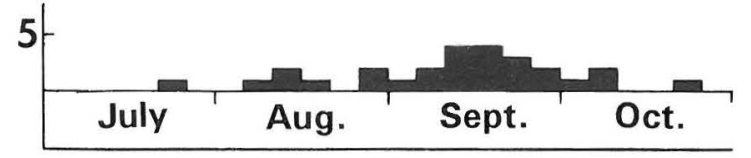

Fig. 9. Fruiting period of Mythicomyces corneipes, according to the material cited in the present paper and by Redhead and Smith (1986), divided into pentads. 
man 1983, Redhead \& Smith 1986), where it had been placed by Karsten (1879). The generic relationships are obscure, Redhead and Smith placed the genus provisionally in the Strophariaceae, mainly basing their treatment on spore characters, e.g. spore colour.

Macroscopically, the species resembles a small Hypholoma in the colouration of the pileus and lamellae. The corneous stipe resembles that of a Marasmius or Phaeocollybia. Under the microscope the species can be mistaken for a Galerina or even Inocybe. The macroscopic features distinguish Mythicomyces easily from Inocybe, it is mainly differentiated from Galerina by the paler spores. However, the species shows fairly many affinities to Galerina, including the two unreported spore features discussed below. Both the macroscopic and microscopic characters make Mythicomyces easy to identify.

Some unreported features were noted in the present material. A great majority of the spores have a small plage. It is not easily observed under the microscope due to the inconspicuous spore sculpture: the warts are hardly visible in optical section. The small plage is also seen in the scanning electron micrograph published by Redhead and Smith (1986: fig. 2). The other unreported spore character, also noted in the Norwegian material (S. Sivertsen, in litt.), is the clear dextrinoid reaction of the spores.

The amyloid reaction of the cystidia has not been reported earlier, but was observed in the Norwegian material (S. Sivertsen, in litt.). The thickened wall seems to have a dual structure especially at the apex. Most of the wall is inamyloid and the amyloid reaction is more or less clearly localized. The reaction is seen in most collections, being relatively frequent within a mount when present. More rarely, it is seen in lower parts.

A typical feature is also the irregularity of the cystidial wall thickness. The walls quite often show more clearly thickened areas or even form large protuberances inward. Apical crystals are variably present, but were noted in some amount in all the collections. Occasionally, the apices are seen to be surrounded by a hyaline globose body in both Melzer's reagent and lactic acid.

Redhead and Smith (1986) selected a rather distant neotype for the species. Nevertheless, this specimen is illustrated in colour (Smith 1949) and matches well with the plate by Fries (1877-1884) and the Finnish material. The neotype differs slightly in microscopical features, as its cystidia often lack a pedicel. According to our measurements, the spores of the neotype have the following dimensions: $7-8(-9) \times 4.5-5(-5.2) \mu \mathrm{m}$, average $7.7 \times 4.8 \mu \mathrm{m}, \bar{Q}=$ 1.6.

\section{Material studied}

Finland. Varsinais-Suomi: Kaarina, Kuusisto, Juopinkrotti, 1989 SH 89/20 (TUR); 1989 SH $89 / 66$ (TUR); 1989 SH \& JV 4179 (TURA, OULU), 4180 (TURA); 1990 JV \& SH 90/291, 90/292 (TUR), 90/290 (H, TUR, UPS); SH \& JV 5436F, 5439 (TURA). Koillismaa: Kuusamo, Oulanka National Park, Kiutaköngäs, 1970 Ulvinen (OULU).

Sweden. Värmland: Molkom, Karlbergshöjden, 1984 Stålberg 84/77 (TURA). Location not indicated, 1905 Lloyd (S).

Norway. Nord-Tröndelag: Grong, near railway station, 1976 Sivertsen (TRH, ZT); 1978 Sivertsen (TRH).

Canada. British Columbia: Glacier Nat. Park, 1980 Redhead (TUR, ex DAOM 178138). Manning, 1985 Kroeger (TUR, ex DAOM 196097). Nova Scotia: Kings Co., Waterville Mt., 1968 Harrison 7902A (MICH). Ontario: Lake Timagami, 1936 Smith, Biggs \& Cain 4443 (MICH).

U.S.A. Colorado: San Miguel Co., San Juan Mts., 1956 Smith 52716 (MICH). Idaho: Valley Co., Payette Nat. Forest, 1956 Smith 53484 (MICH); Payette Lakes, in boggy area, X.1943 W.B. Gruber P-88. Oregon: Clackamas Co., Mt. Hood, 1947 Smith 27500 (MICH).

Acknowledgements. We wish to thank the Board of Environmental Conservation of the commune of Kaarina for supporting financially the printing of the colour photograph. We received material and/or valuable information from the following persons/herbaria: Mr. Johan Nitare (Jönköping, Sweden); Ms. Esteri Ohenoja, Lic. Phil. (OULU); Dr. Scott A. Redhead (DAOM); Dr. Svengunnar Ryman (UPS); Dr. Robert L. Shaffer (MICH); Dr. Sigmund Sivertsen (TRH); Dr. Åke Strid (S), Mr. L. Stridvall (Trollhättan, Sweden). Their cooperation is warmly appreciated. The linguistic revision of the manuscript was done by Ms. Anna Damström, M.A.

\section{References}

Cailleux, A. 1981: Code des couleurs des sois. - Boubée.

Fries, E.M. 1877-1884: Icones selectae Hymenomycetum nondum delineatorum. 2. - 104 pp., 100 pl. Berling, Holmiae \& Upsaliae.

Guzmán, G. 1983: The genus Psilocybe. A systematic revision of the known species including the history, distribution and chemistry of the hallucinogenic species. - Beih. Nova Hedwigia $74: 1-439$, pls. $1-40$.

Karsten, P.A. 1879: Rysslands, Finlands och Skandinaviska halföns hattsvampar. - Bidr. Känned. Finlands Nat. Folk $32: 1-571$

Küppers, H. 1981: DuMont's Farben-Atlas. 2nd ed. - 163 pp. DuMont Buchverlag, Köln.

Redhead, S.A. \& Smith, A.H. 1986: Two new genera of agarics based on Psilocybe corneipes and Phaeocollybia perplexa. - Canadian J. Bot. 64:643-647.

Smith, A.H. 1949: Mushrooms in their natural habitats. I-II. 626 pp., 231 stereo-photographs. Sawyer's Inc., Portland.

Stålberg, J. 1991: Mythicomyces comeipes (Fr.) Redhead \& Smith. Mystisk skivling identifierad. - Jordstjärnan 12:64-67.

Stridvall, A. \& Stridvall, L. 1991: X Nordic Mycological Congress. Håverud, Dalsland (Sweden), 10-15 September 1990. List of species. - 28 pp. Länsstyrelsen i Älvsborgs län, Vänersborg.

Received on 12 February 1991 